\title{
Entrepreneurship: An Educational Perspective (The Case Of Slovenia - Compared To Developed Economies)
}

Vlado Dimovski, (E-mail: Vlado.Dimovski@uni-lj.si), University of Ljubljana, Slovenia Jana Žnidaršič, (E-mail: jana.znidarsc), University of Ljubljana, Slovenia

\begin{abstract}
Challenges of modern economy are forcing the developed countries to seek comparative advantages mainly in their human resources - in the trained, educated, flexible and self-confident workforce. Lifetime learning, continuous training and systematic development of entrepreneurial and managerial skills are becoming the basic need for any developed and/or developing country. Well-educated people with the above mentioned characteristics are initiators of high-tech and dynamic entrepreneurship, which is without doubt the main factor of development. Considering the fact that Slovenia is still far away from ideal entrepreneurial society in which entrepreneurship is the way of life for the majority of its population as well as taking into account that Slovenian entrepreneurs and managers have much lower education than their American counterparts we come to the conclusion that Slovenia should focus much more on entrepreneurial and managerial education. For these reasons we are going to discuss the following hypotheses:

1. Slovenia needs to expand its entrepreneurial activity in general, especially dynamic and high-tech entrepreneurship to compete successfully on the European market.

2. The psychological profile of Slovenian people and/or entrepreneurs is closer to the profile of employees than to dynamic entrepreneurs.

3. Dynamic entrepreneurship requires a higher educational level than Slovenian entrepreneurs posses.

4. $\quad$ Slovenia should improve its educational structure.

5. Entrepreneurial education should involve the implementation of modern, active learning methods.

6. Active teaching (learning) methods contribute to the development of entrepreneurial characteristics.
\end{abstract}

\section{Introduction}

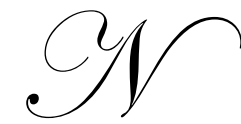

owadays, challenges such as globalization and global competition, transition from industrial to new economy, technology and e-business, reorganization as well as the issues encompassing ethics, social responsibility, cultural differences, etc. clearly indicate the uncertainty of our future. Even unlimited amounts of goods and services cannot guarantee prosperity and material security to the citizens in any country or society.

The developed countries, including Slovenia, will seek comparative advantages mainly in their human resources - in the trained, educated, flexible and self-confident workforce. Human resource investment is the most crucial and basic investment, which enables further successful economic and social growth and development (Burton-Jones, 1999). Lifetime learning, continuous training and systematic development of entrepreneurial and managerial characteristics are becoming a basic need for any developed as well as developing country. 
On the other hand, the crucial influence of entrepreneurship on growth, new job creation, innovation and general prosperity (Birch, 1993; Smallbone, 1995) has been widely accepted, particularly in intellectual circles. While considering the strong connection between entrepreneurial activity and educational level, we are going to discuss the implementation of entrepreneurial education and its influence on entrepreneurial phenomenon more in detail.

This paper focuses on the comparison of entrepreneurial activity by country (1), it highlights the significant role of education on entrepreneurial and managerial activity (2), it shows the comparison between educational level of Slovenian entrepreneurs and managers and their American counterparts (3), and compares characteristics of entrepreneurial education in some European countries, Australia, the USA and Slovenia (4), finally, it discusses the necessity of implementing modern learning methods in entrepreneurial and managerial education - giving the results from the survey about implementing of modern teaching methods in entrepreneurial education on the secondary school level (5). The main aim of this study is to establish weaknesses and give suggestions for improving and developing entrepreneurial education in Slovenia.

\section{Why support entrepreneurial activity?}

Research studies have identified some crucial objectives that appeared to drive entrepreneurial policy at the national level: to increase competition, to strengthen the production chain, to diversify the economy, and to create employment and reduce unemployment (Smallbone, 1995). There are many other positive impacts of entrepreneurial activity (Birch in Možina et al., 1994; Bojović, 1989; Glas, 2000; OECD, 1998; Setnikar-Cankar, 1993; Vahčič, 2000; Vidovič-Tomanovič, 1999; GEM, 2001; EC 2003): discovering opportunities and their implementation, the contribution of entrepreneurial activity as a source of innovation and development of a diversified economic structure, the contribution of SME's as a "seed-bed" from which large companies can grow, enabling balanced regional development and the contribution of entrepreneurial activity to economic growth in general (costs are lower, productivity is higher, GDP expands, economic prosperity enables social and political stability).

\section{What makes a country entrepreneurial?}

Global Entrepreneurship Monitor Analysis (Reynolds, Camp, Bygrave, Autio, Hay, 2001) has clearly demonstrated that the level of entrepreneurship varies from country to country. Entrepreneurship is a social phenomenon which is influenced by different economic and non - economic conditions. Economic conditions include: access to profits, the existence of leading teams, opportunities, chances, capital and human resources, entrepreneurial education, etc. Non-economic factors can be grouped as non-economic motives (the need for achievement, the need for independence, dissatisfaction with the current job, the need for power and control over the situation), values (ethics, personal opinion, optimism, responsibility, honesty, rationality, etc.) and environmental factors (economic stability, open economy and free market, private ownership system, encouraging economic policy, developed entrepreneurial culture).

\section{Entrepreneurial activity by country: International comparison of countries included in the Global Entrepreneurship Monitor (GEM) Analysis}

The overall level of entrepreneurial activity for each country is represented by the TEA (Total Entrepreneurial Activity) index; the value shows the number per every 100 adult individuals who are trying to start a new firm or are the owners / managers of an active business less than 42 months old (Figure 1).

When countries are grouped according to global regions, it can be established that the 16 European countries plus Israel form one rather homogenous group with an average prevalence rate of about 8 percent. In Asian countries (India, Japan, Korea and Singapore) the average is about 9 percent, Canada and the USA have an average prevalence rate of approximately 11.3 percent, three other former British colonies (Australia, New Zealand, South Africa) average almost 14 percent, and Latin American countries (Argentina, Brazil, Mexico) have an average rate of 14.5 percent. 
About 54 percent of those involved in creating and growing new firms claimed that they were pursuing a business opportunity for personal interest and at the same time they often worked in a regular job. These efforts are referred to as »opportunity entrepreneurship«, reflecting the voluntary nature of participation. In contrast, about 43 percent reported they were involved because they had »no better choices for work «. Such efforts are referred to as »necessity entrepreneurship «, reflecting the individual's perception that such actions present the best option available for employment but not necessarily the preferred one. The remaining 3 percent involved in new business activity reflect other motivations.

In terms of opportunity entrepreneurship the leading countries are New Zealand, Australia, Mexico, the USA, Ireland, Brazil, and Korea. As for necessity entrepreneurship the leading countries are mainly the less developed ones, such as India, Mexico, Brazil, Korea, Poland, Hungary and Argentina. Northwestern European countries have a very low percentage of necessity entrepreneurship. According to the general TEA index classification, Slovenia ranked rather low - between 25 and 28 among 37 countries (Figure 1).

\section{Entrepreneurial activity in Slovenia}

During the 1990s, Slovenia experienced a wave of entrepreneurship, bringing the number of incorporated businesses up from 4,112 in 1989 to 56,473 in 1999 and the number of sole proprietors from 35,479 in 1991 to 65,346 in 1999 (Statistical Yearbook of Slovenia, 2001). In spite of the growth of new venture creations, some important structural problems are still hampering Slovenian economic competitiveness. There are three weaknesses: (1) the new private ventures are still mostly micro businesses (Badrljica, 2002 ) and their growth is very slow; consequently, there is lack of core small businesses in the size-class of $11-50$ employees, (2) the current GDP p. c level in Slovenia indicates that the service sector is still underdeveloped and (3) the share of innovative, new technology - based firms is virtually negligible. After 1994, the spontaneous wave of entrepreneurship was exhausted and the entrepreneurial pool was not strong enough for high - tech and growth oriented start - ups. Considering the crucial influence of entrepreneurship on growth, new job creation, innovation and general prosperity, we can confirm the first hypothesis that "Slovenia needs to expand its entrepreneurial activity in general, especially dynamic and high-tech entrepreneurship to compete successfully on the European market".

\section{The reasons for such situation}

Empirical research of personality traits of Slovenian entrepreneurs showed that the most desired entrepreneurial characteristics (Begley, Boyd, 1995; Chell, Haworth, Brearley, 1991) including responsibility, working enthusiasm, endurance, initiative, self-confidence, creativity, and innovation are rated low (Musek, 1994). Vision, risk-taking, leadership, criticism and ethical values are ranked even lower. The psychological profile of Slovenian entrepreneurs is closer to the profile of employees than to dynamic entrepreneurs - hypotheses 2 (Musek, 1994; Trstenjak, 1991). The trend is partly connected with the Slovenian employment history of primarily farmers and craftsmen. In the past, most managers and industrialists were foreigners who left Slovenia after 1945. In addition, fifty years of socialism have not created a typical entrepreneurial environment and culture. The recent level of entrepreneurial activity in Slovenia needs to be expanded, mostly by developing activities connected with up-to-date knowledge in the field of technology as well as in the field of business. Prosperity of high-tech and fast growing enterprises can be achieved primarily by educating potential young entrepreneurs (GEM, 2001, page 17). We are not only facing lack of entrepreneurial and management knowledge but also lack of technological and organizational skills, as well as legal knowledge. The comparison with other countries shows that Slovenia is still not focused enough on educating its active and potential entrepreneurs and managers. 
Figure 1: Necessity and Opportunity-Based

Entrepreneurial Activity by Country (TEA index 2002)

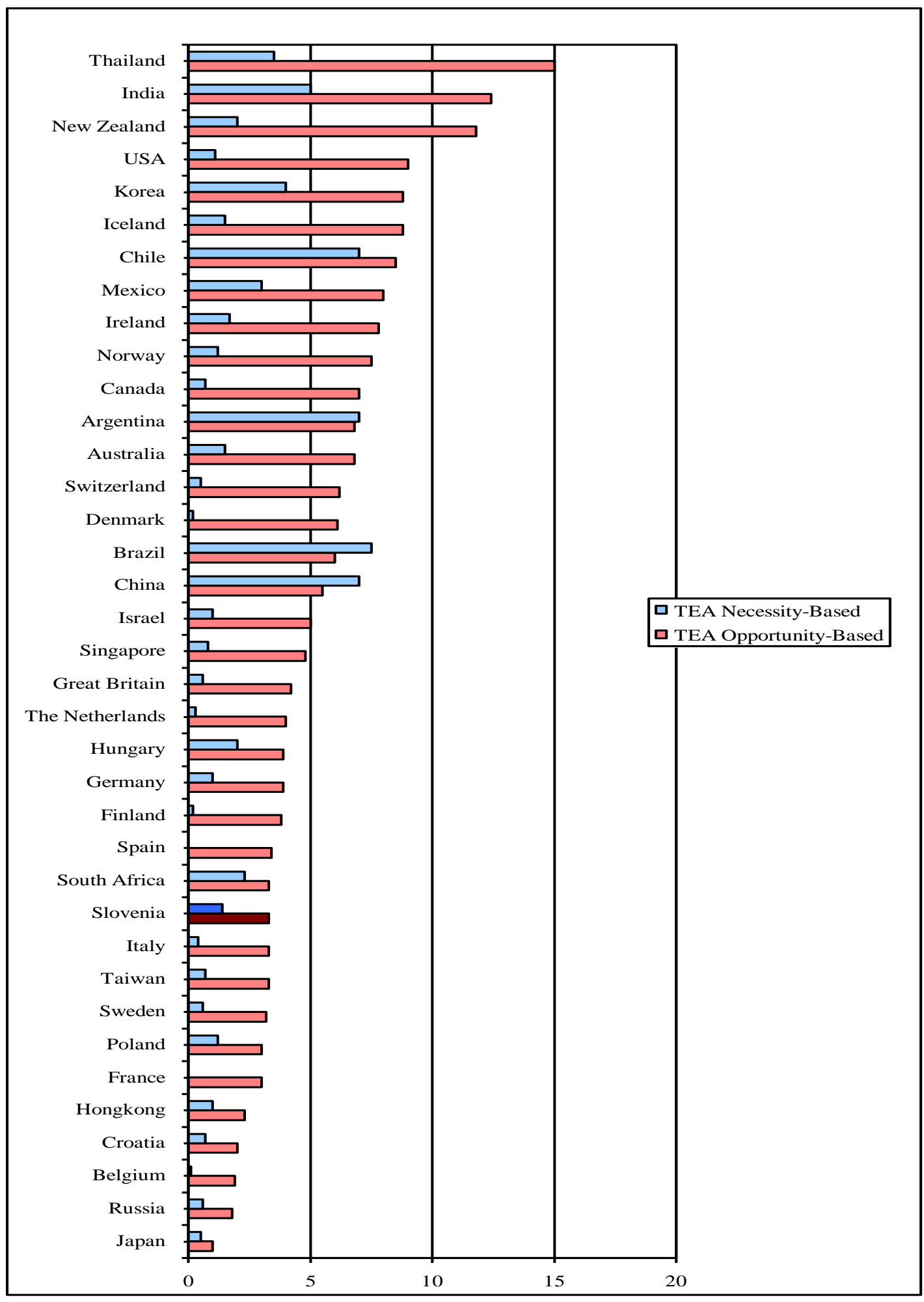


Source: GEM, Slovenia 2002, Finance No. 220, November 2002.

The comparison between the educational level of Slovenian entrepreneurs and managers and their American counterparts is shown in Table 1.

Table 1: Population (completed 15 years) by educational level (Proportions, Census, 1991); Comparison between educational level of Slovenian entrepreneurs and managers (Results of survey, 2000) and American entrepreneurs and managers $(1996, \%)$.

\begin{tabular}{|l|c|c|c|c|c|c|c|}
\hline \multicolumn{1}{|c|}{$\begin{array}{c}\text { Education } \\
\text { Level }\end{array}$} & $\begin{array}{c}\text { Citizens } \\
\text { Slovenian } \\
\text { Population }\end{array}$ & $\begin{array}{c}\text { Employees in } \\
\text { Companies, } \\
\text { Enterprises and } \\
\text { other org. 2000 }\end{array}$ & $\begin{array}{c}\text { Entrepreneurs } \\
\text { (all) 2000 }\end{array}$ & $\begin{array}{c}\text { Entrepreneurs } \\
\text { (self-employed) } \\
\mathbf{2 0 0 0}\end{array}$ & $\begin{array}{c}\text { Slovenian } \\
\text { Managers }\end{array}$ & $\begin{array}{c}\text { American } \\
\text { Entrepreneurs } \\
\mathbf{1 9 9 6}\end{array}$ & $\begin{array}{c}\text { American } \\
\text { Managers } \\
\mathbf{1 9 9 6}\end{array}$ \\
\hline $\begin{array}{l}\text { Unfinished or } \\
\text { finished Primary } \\
\text { School }\end{array}$ & 47.6 & 52.5 & 1.4 & 3.4 & none & none & none \\
\hline $\begin{array}{l}\text { Vocational and } \\
\text { Secondary School }\end{array}$ & 43.4 & 27.8 & 53.9 & 73.2 & 9.8 & 8.5 & 3.1 \\
\hline College & 4.6 & 8.3 & 17.6 & 11.7 & 18.3 & 26.7 & 3.9 \\
\hline $\begin{array}{l}\text { University, } \\
\text { post-graduate }\end{array}$ & 4.4 & 11.8 & 27.1 & 11.7 & 71.9 & 63.6 & 93.0 \\
\hline Total & 100 & 100 & 100 & 100 & 100 & 100 & 100 \\
\hline \multicolumn{1}{|c|}{ Source: } & $\begin{array}{c}\text { SLO in } \\
\text { figures. }\end{array}$ & $\begin{array}{c}\text { StatYearbook SLO, } \\
2002\end{array}$ & Sisan 2000 & Sisan 2000 & $\begin{array}{c}\text { Glas, } \\
\text { Drnovšek }\end{array}$ & $\begin{array}{c}\text { Glas, } \\
\text { Drnovšek, } \\
1999\end{array}$ & $\begin{array}{c}\text { Glas, } \\
\text { Drnovšek } \\
, 1999\end{array}$ \\
\hline
\end{tabular}

If we exclude employees in leading positions and government employees, relatively low educational levels together with business illiteracy result in a small pool of entrepreneurial talents. In order to foster future growth of small businesses it is important to stimulate young generations to continue their education at the graduate level.

The influence of educational institutions on developing:

Entrepreneurial and managerial characteristics and on fostering entrepreneurial activity in general

Among conditions affecting entrepreneurial activity educational attainment has been exposed. Entrepreneurial activity in a certain country is significantly positively related to entrepreneurial knowledge and qualifications (GEM, 2001, p. 23). Education is however, related to the type of economic activity and expected firm's growth (GEM, 2001, p.17; Erikson, 2001); the percentage of entrepreneurs anticipating substantial growth was significantly higher (31 percent) in those with graduate experience. People with higher education are more open to team work and tend to join their capital or firm with partners, thus enabling the firm's growth. Educated entrepreneurs are more self-confident and are not afraid of failure. We can confirm the third hypothesis, that "dynamic entrepreneurship requires a higher educational level than Slovenian entrepreneurs posses". However, most Slovenian potential and active entrepreneurs lack the desired entrepreneurial characteristics. In addition, Slovenian entrepreneurs and managers have much lower education than their American counterparts. These two facts indicate that Slovenia should focus much more on entrepreneurial and managerial education (hypothesis 4) in striving to become ideal entrepreneurial society in which entrepreneurship is the way of life for the majority of its population.

Research shows that education is the most important factor influencing the growth of enterprises as well as the entrepreneurial activity in general. It also determines the development of entrepreneurial characteristics and behavior of people. Therefore, some major characteristics of entrepreneurial education in some European countries, Australia, the USA and Slovenia are discussed in the following section. 


\section{Entrepreneurial Education by Country}

There are a number of cultural, legislative and other differences identified in the countries that affect the understanding and practical application of enterprise education - different programs, methods etc. (Hytti, 2002). Entrepreneurship and enterprise education appear to have a variety of learning objectives. We categorize them under the following three headings (Hytti, 2002, p.5):

1. Learning to understand entrepreneurship (increasing the enterprising attitudes and awareness of the importance of entrepreneurship);

2. Learning to become entrepreneurial (developing entrepreneurial characteristics and behavior);

3. Learning to become an entrepreneur (increasing the enterprising skills and knowledge).

Programs, levels and targets of entrepreneurial education by country are shown in Table 2.

Table 2: Programs, Levels and Targets of Entrepreneurial Education in European Countries

\begin{tabular}{|c|c|c|c|c|c|c|c|}
\hline \multicolumn{4}{|c|}{ Educational Level } & \multicolumn{3}{c|}{ Targets of Entrepreneurial Education } \\
\hline $\begin{array}{c}\text { Number of } \\
\text { Country }\end{array}$ & $\begin{array}{c}\text { Under } 6 \\
\text { years }\end{array}$ & $6-12$ & $13-19$ & University & $\begin{array}{c}\text { Promotion } \\
\text { foundation of } \\
\text { new start-ups }\end{array}$ & $\begin{array}{c}\text { Understanding and } \\
\text { awareness of the } \\
\text { importance of } \\
\text { entrepreneurship }\end{array}$ & $\begin{array}{c}\text { Developing of } \\
\text { entrepreneurial } \\
\text { characteristics }\end{array}$ \\
\hline Austria (13) & 0 & 0 & 4 & 10 & 13 & 6 & 2 \\
\hline Finland (11) & 3 & 5 & 6 & 10 & 2 & 11 & 9 \\
\hline Ireland (14) & 1 & 3 & 7 & 11 & 10 & 7 & 2 \\
\hline Norway (11) & 0 & 1 & 2 & 12 & 9 & 7 & 9 \\
\hline $\begin{array}{c}\text { Great Britain } \\
(13)^{*}\end{array}$ & 0 & 1 & 9 & 11 & 9 & & \\
\hline
\end{tabular}

* The sum of different programs, reflecting certain educational level are not equal with the number of programs - given for each country, because some of the programs involve different levels (they can be applied on different, successive levels

Source: Table 2 was formed by using the data from Hytti et al., 2002, pp. 45-50 and using the data on the Internet address, www.Entredu.com.

In spite of the fact that Austrian programs do not involve pupils under the age of 12, implemented entrepreneurial programs (13) follow all three goals mentioned in Table 2, with the main goal to prepare people to establish their own company.

The Norwegian educational system has traditionally not focused on entrepreneurship or SMEs. Over the last decade, and particularly the last five years, this tendency has changed. The fact that the number of entrepreneurs in Norway is decreasing in comparison with other OECD countries has raised increased public concern. In the spring of 1999, the Norwegian government included entrepreneurship into curricula and the need for enterprise education has been stressed through four motives: (1) Encouraging pupils to create their own jobs - to become the entrepreneur, (2) Developing entrepreneurial knowledge and skills, which is beneficial, regardless of whether a person becomes an entrepreneur or not, (3) Arousing interest in working with entrepreneurs or in establishing their own businesses and (4) Helping students familiarize themselves with the local community and the use of local resources. The main goal of implementing entrepreneurial programs is to foster the establishment of new start-ups (Austrian model) as well as to establish a strong link between schools, local authorities and economy to create a good base for enterprise activity.

Entrepreneurial education targets in Finland, Ireland and Great Britain are more ambitious than those in Austria and Norway. Their programs realize all three goals of entrepreneurial education (Table 2) and are focused mainly on developing entrepreneurial characteristics in general. Enterprise education includes everybody within the school system and aims at developing: (1) an entrepreneurial attitude which is a combination of flexibility, initiative, risk- taking ability, self-direction and cooperation skills as well as strong motivation for achievement, (2) knowledge 
of entrepreneurial activity, (3) knowledge of the requirements of entrepreneurial activity from the point of view of career orientation and further studies. The overall objective is that schools and education institutions together with their interest groups develop the students' basic awareness of the importance and possibilities offered by entrepreneurial activity. In the basic curriculum of comprehensive schools, enterprise education is included as subject of its own right. In higher secondary school, entrepreneurship is approached either by starting a specific subject area of enterprise education or by including entrepreneurship courses in suitable subject areas or as separate courses. All vocational examinations include basic entrepreneurial skills. Enterprise education also includes teacher training. Teaching methods emphasize the action orientation of both, individuals and groups. Especially in Great Britain, there is great awareness of the important role of entrepreneurial activity as well as of the role of education in the entrepreneurial process. In the past 20 years the British government has been supporting entrepreneurial education at different levels (from kindergartens to the university level). Basic entrepreneurial knowledge is offered to everybody involved in the formal education system and entrepreneurial spirit is widely spread among people. Governmental, economic and educational institutions act simultaneously to promote the development in this direction.

Australia has highly developed its formal entrepreneurial education. Children obtain basic entrepreneurial education from the first class of primary school on (Figure 2). Entrepreneurial contents are spread through the entire curriculum and introduced into the curriculum step by step. On the first level (1-5 class of primary school) children start to learn basic terms connected with entrepreneurship thus becoming aware of the importance and possibilities that entrepreneurship offers. They are additionally motivated to solve different problems by using modern, active learning methods within »learning by doing « concept. This concept enables children to develop their entrepreneurial skills from the very beginning of their formal education thus creating the base for the further implementation of entrepreneurial education.

Upper classes of primary and secondary school offer the superstructure of entrepreneurial learning by enabling pupils to detect entrepreneurial opportunities and develop their entrepreneurial characteristics and skills. They learn about the start-up phase and become familiar with other phases of the entrepreneurial process. Entrepreneurial study can be continued on the faculty level resulting in employment or self-employment. Additional training and life-time learning offer the adults specialist knowledge (e.g. establishing a company, its growth potentials, leadership, etc.); Australian model is shown in Figure 2.

The objectives of entrepreneurial education in Australia are categorized as follows:

- $\quad$ entrepreneurship role awareness,

- $\quad$ positive attitude of the general public towards entrepreneurship and entrepreneurial activity,

- entrepreneurship carrier as one of the possibilities,

- understanding the entrepreneurial process and the firm's growth through the different stages of its development, life-cycle of the firm,

- development of entrepreneurial characteristics as well as skills and knowledge - needed to establish a new company.

Australia is achieving these objectives by implementing 30 different programs involving entrepreneurial education. It is not only the students that need to be prepared for the world of work outside the school. According to the enterprise education programs, it is evident that teachers also need training and assistance. The training of teachers has a central role in promoting enterprise education since it has been proven that the teachers who are more familiar with entrepreneurship (i.e. entrepreneurial experience) possess the best prerequisites to teach in this field.

The American entrepreneurial education system is very sophisticated and widely spread. There are many entrepreneurial schools for pupils of different age and even more entrepreneurial programs (Dragar, 1999, pp. 1213). Entrepreneurial programs are divided according the following criteria: (1) entrepreneurship awareness, (2) entrepreneurship readiness and (3) entrepreneurship application - programs engaged in practical implementation of entrepreneurial knowledge mainly for starting a new business. 
Figure 2: Model of entrepreneurial education development in lifetime learning concept in Australia

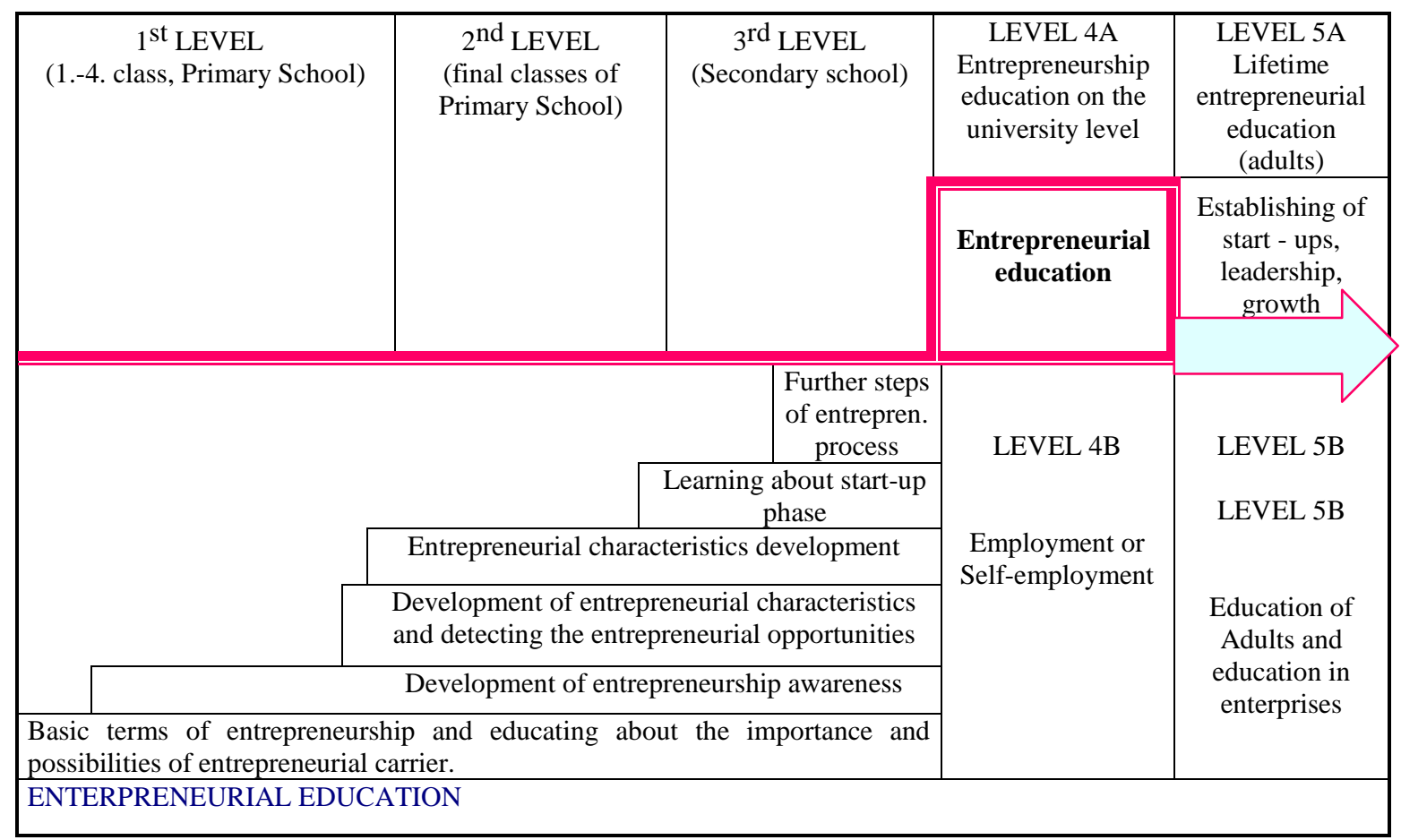

Source: Morris and Wingham, stated in Dragar, 1999, p. 11.

American educational programs based on general business knowledge and dubbed as "Junior Achievement" are implemented all over the world. These programs include an optional module in which real business is simulated; firms are formally established, the business is conducted, and at the end of school the enterprise is closed down. Entrepreneurial programs have different goals and they are focused on different kinds of pupils and different environments (e.g. entrepreneurial programs especially for the inner-city youth surrounded by drugs or misery). All programs are tested through 4 phases: pilot phase, improvement and correction of the program, secondary testing on various groups and finally mass implementation of the program and qualificationtraining of teachers.

\section{Entrepreneurial education in Slovenia}

Before 1980, entrepreneurship in Slovenia as well as in other socialist countries was not considered an important factor for economic and social development. A different economic situation and the need to implement market - oriented economy called for people with well-developed entrepreneurial and managerial characteristics, skills and knowledge. According to Petrin (1998), the most important terms of reference during the transition period are the following: (1) how to establish an enterprise and how to ensure its growth, (2) how to restructure and modernize the existing enterprise (intrapreneurship) and (3) how to create the entrepreneurial infrastructure and networks. In the 1990s, the government realized the need for entrepreneurial education (in the 1980s, only a few enthusiasts from the Faculty of Economics advocated the importance of entrepreneurial education for our future development). In the 1990s, the Ministry for labor, family and social affairs was faced with a serious problem of great unemployment which was softened by self-employed programs.

The implementation of entrepreneurial education in Slovenia was introduced in the following stages: (1) the founding of GEA College in February 1990 - at the time it was the first and leading institution for informal 
entrepreneurial education in Slovenia, (2) entrepreneurial education at the Faculty of Economics in Ljubljana (1993) and Maribor (1994), (3) introduction of entrepreneurial education into secondary schools by adopting foreign entrepreneurial projects and programs mainly from Austria and Great Britain, (4) the founding of GEA College of Entrepreneurship in Piran, (5) Entrepreneurial Center at the Faculty of Economics (Alumni, February 2003, p. 17), (6) the recent development of the interdisciplinary oriented incubator at the Faculty of Economics in Ljubljana serving as the link between students from different universities working on projects of new firms.

Entrepreneurship as a secondary school subject was systematically introduced in 1994 in cooperation with Durham University Business School. Formal education in primary schools does not include entrepreneurship although there are some enthusiastic teachers who run entrepreneurial circles thus involving children at an early age. On the secondary school level there are many entrepreneurial activities, such as business plan competition dubbed "Young entrepreneur" organized by GEA College of Entrepreneurship every year and "learning firm" project in which pupils simulate a business environment from the start-up of the firm. The program is optional, but it is run at the majority of secondary schools in Slovenia. "Alpe-Adria" international fair is yet another chance for young entrepreneurs to present their entrepreneurial ideas and plans. GEM experts (Glas, 2002) claim that entrepreneurial education in Slovenia should be more deeply involved in other subjects' curricula by implementing modern learning methods as many teachers use traditional teaching methods.

On the faculty level, Slovenian entrepreneurial and managerial programs are completely comparable with western countries. Entrepreneurship program at the Faculty of Economics in Ljubljana is the same as the one at the Stirling University and involves cooperation with many distinguished foreign professors). Entrepreneurial and managerial programs at the Ljubljana as well as the Maribor faculty were formed under the so- called TEMPUS program in cooperation with four faculties from Sweden (University College of Boras, University of Gothenburg, School of Business and Commercial Law), Belgium (University of Gent, De Vlerick School of Management) and Italy (University of Udine, Faculty of Economics and Banking). At the end of the program, students have tested their knowledge by working in enterprises.

\section{Different learning methods and development of entrepreneurial characteristics}

Economic, cultural and political changes, values and relationships we are facing nowadays are totally incompatible with traditional teaching methods, as they do not foster desired entrepreneurial characteristics. The comparison between traditional and entrepreneurial teaching model in shown in Table 3.

Table 3: The comparison between traditional teaching model and entrepreneurial model

\begin{tabular}{|c|c|}
\hline Traditional model & Entrepreneurial model \\
\hline 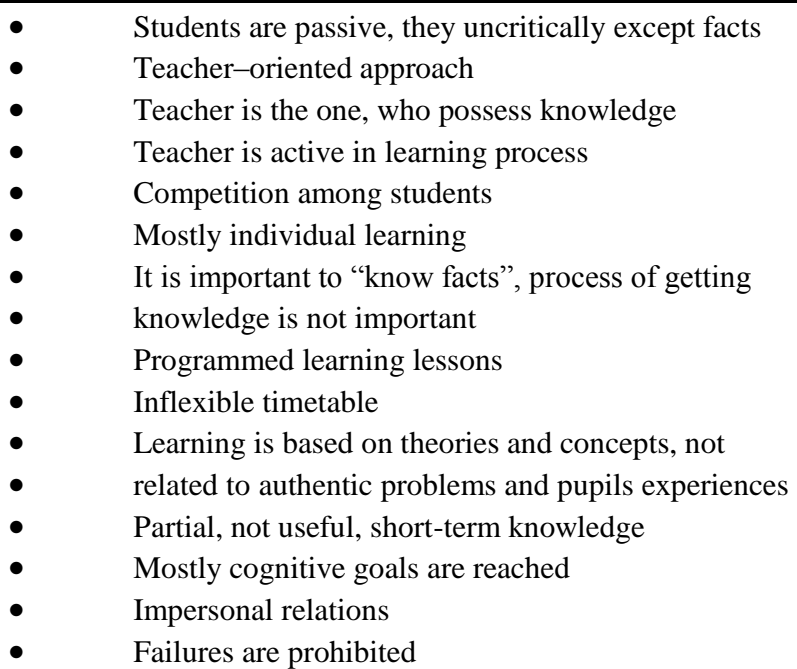 & $\begin{array}{ll}\text { - } & \text { Students are active } \\
\text { - } & \text { Student-oriented approach } \\
\text { - } & \text { Students learn from different sources } \\
\text { - } & \text { Teoperative learning, open communications } \\
\text { - } & \text { Teacher acts as coach and mentor } \\
\text { - } & \text { Focus on the process of getting knowledge and } \\
\text { - } & \text { quality of knowledge is important } \\
\text { - } & \text { Learning in authentic environment } \\
\text { - } & \text { Transparent learning objectives } \\
\text { - } & \text { Useful knowledge } \\
\text { - } & \text { Cognitive and affective-motivative goals } \\
\text { - } & \text { Personal relations } \\
\text { - } & \text { Multidisciplinary and interactive learning } \\
\text { - } & \text { learning from mistakes, as well as teacher. }\end{array}$ \\
\hline
\end{tabular}


Vir: Gibb, 1994, p. 24; Marentič Požarnik, 2000, p. 282-287; personal view and experiences.

Fostering entrepreneurial activity is strongly connected with potential entrepreneurs - people, possessing entrepreneurial and managerial skills, as well as the most desired entrepreneurial characteristics (Begley, Boyd, 1995; Chell, Haworth, Brearley, 1991) including responsibility, working enthusiasm, endurance, initiative, selfconfidence, creativity, and innovation. Considering the fact that Slovenian entrepreneurs generally do not possess the desired entrepreneurial characteristics, we are facing the question, how educational system can develop such characteristics. Research of implementing different educational methods in entrepreneurial education showed that the impact of learning methods on entrepreneurial characteristics and behavior is significant (Hytti, 2002; Klandt, 1998). According to entrepreneurial education criteria, teaching methods can be classified as follows (Klandt, 1998):

- Degree of activities by the students (it is questioned to what extent the students consider the training process as practice-related). Students can receive information passively, or they learn by themselves "learning by doing" - through interaction with the trainer or media.

- Environment of the training process (it is questioned whether the training process takes place in an artificial environment, usually in classrooms, or within a real existing professional working environment, where entrepreneurs usually act).

- Providing analytical problem solving activities or not (the problem is given to the student in a pre-set and structured manner, rather than identifying the problem and its analysis and possible solution alongside the student).

Classification of teaching methods - considering criteria mentioned above is shown in Table 4.

Table 4: Teaching methods - more or less fitting the criteria exposed

\begin{tabular}{|c|c|c|c|}
\hline Teaching method & $\begin{array}{l}\text { Activity - } \\
\text { students }\end{array}$ & $\begin{array}{c}\text { Environment - } \\
\text { natural }\end{array}$ & \begin{tabular}{|c|}
$\begin{array}{c}\text { Analytical work- } \\
\text { up }\end{array}$ \\
\end{tabular} \\
\hline Traditional methods & - & - & - \\
\hline Simulations & + & o & + \\
\hline Workshops & + & - & + \\
\hline Interactive learning, consulting & + & - & + \\
\hline Case studies - written materials & + & - & $\mathrm{o}$ \\
\hline Case studies - visiting entrepreneurs & $\mathrm{O}$ & + & + \\
\hline Excursions & _ & + & $\mathrm{o}$ \\
\hline Indirect observation (TV, videos) & $\overline{\mathrm{o}}$ & - & o \\
\hline Writing business plans ( with presentation) & + & + & + \\
\hline Training firm & + & o & + \\
\hline Games and competitions & + & o & o \\
\hline Computer/multimedia & + & o & $\mathrm{O}$ \\
\hline Role games & + & o & + \\
\hline Work with entrepreneurs & + & + & $\mathrm{o}$ \\
\hline Papers & + & - & $\mathrm{o}$ \\
\hline Entrepreneurial circles & + & + & + \\
\hline Discusion & + & - & $\mathrm{o}$ \\
\hline Training lectures & $\mathrm{o}$ & - & o \\
\hline Reading books and papers & $\mathrm{O}$ & - & $\mathrm{o}$ \\
\hline Problem solving & + & $\mathrm{o}$ & + \\
\hline
\end{tabular}

Legend: +: fit; -: does not fit; o: indifferent

Source: Klandt, 1998; personal experience

The fit between different teaching methods and the requirements for entrepreneurship training (developing entrepreneurial characteristics) is presented in Table 5. 
There is little doubt that teaching methods have an important influence on the development of entrepreneurial behavior as well as on development of the most desired entrepreneurial characteristics. We focus on the most important including:

1. Developed communicative and social skills (team-working, negotiating etc.),

2. High need of achievement (high n-ach),

3. Moderate risk tendency (n-risk), excluding hazard,

4. Internal locus of control,

5. High need of independence (high n-indep.), excluding authoritarian teaching methods and including equal position of teachers and students,

6. Model orientation (with successful entrepreneur as guest lecturer or guru).

Table 5: Teaching methods and entrepreneurial characteristics that are developed using certain method

\begin{tabular}{|c|c|c|c|c|c|c|}
\hline \multirow[b]{2}{*}{ Teaching method } & \multicolumn{6}{|c|}{ Entrepreneurial characteristics } \\
\hline & $\begin{array}{l}\text { Communicative } \\
\text { and social skills }\end{array}$ & N-ach & $\begin{array}{c}\text { Moderate } \\
\text { risk } \\
\text { tendency }\end{array}$ & \begin{tabular}{|c|} 
Internal \\
locus of \\
control
\end{tabular} & N-indep & $\begin{array}{c}\text { Model } \\
\text { orientation }\end{array}$ \\
\hline Traditional methods & -- & -- & -- & -- & -- & -- \\
\hline Simulations & ++ & $\mathrm{O}$ & $\mathrm{O}$ & + & + & ++ \\
\hline Workshops & $\mathrm{O}$ & + & $\mathrm{o}$ & $\mathrm{O}$ & $\mathrm{o}$ & $\mathrm{O}$ \\
\hline Interactive learning, consulting & + & ++ & ++ & + & ++ & + \\
\hline Case studies - written materials & o & + & $\mathrm{O}$ & + & + & ++ \\
\hline Case studies - visiting entrepreneurs & + & $\mathrm{o}$ & $\mathrm{O}$ & + & + & ++ \\
\hline Excursions & o & $\mathrm{O}$ & $\mathrm{o}$ & + & $\mathrm{O}$ & ++ \\
\hline Indirect observation (TV, videos) & - & $\mathrm{O}$ & $\mathrm{O}$ & o & $\mathrm{O}$ & ++ \\
\hline $\begin{array}{l}\text { Writing business plans ( with } \\
\text { presentation) }\end{array}$ & ++ & ++ & $\mathrm{O}$ & ++ & + & ++ \\
\hline Training firm & + & ++ & $\mathrm{O}$ & ++ & ++ & ++ \\
\hline Games and competitions & ++ & ++ & ++ & + & + & $\mathrm{O}$ \\
\hline Computer/multimedia & - & + & O & $\mathrm{O}$ & $\mathrm{O}$ & $\mathrm{O}$ \\
\hline Role games & ++ & $\mathrm{O}$ & $\mathrm{O}$ & + & ++ & ++ \\
\hline Work with entrepreneurs & + & + & ++ & + & ++ & ++ \\
\hline Papers & ++ & ++ & + & - & ++ & - \\
\hline Entrepreneurial circles & + & ++ & $\mathrm{O}$ & + & + & + \\
\hline Discusion & + & o & $\mathrm{O}$ & + & + & o \\
\hline Training lectures & $\mathrm{O}$ & $\mathrm{O}$ & $\mathrm{O}$ & $\mathrm{O}$ & + & $\mathrm{O}$ \\
\hline Reading books and papers & o & $\mathrm{O}$ & $\mathrm{O}$ & + & ++ & + \\
\hline Problem solving & + & ++ & ++ & ++ & ++ & ++ \\
\hline
\end{tabular}

Legend: +: fit; -: does not fit; o: indifferent; --: absolutelly does not fit ; ++: absolutelly fit

Source: Klandt, 1998; personal experience

Research and experience proved that active learning methods, including unstructured problems and tasks, especially when used in authentic environment, are the basic tool of entrepreneurial education, as they develop some of the most important entrepreneurial characteristics (hypothesis 6).

A closer examination showed that the methods (Table 5) which develop entrepreneurial characteristics also fit the criteria from Table 4. This fact confirms the hypotheses 5 and 6 that "entrepreneurial education needs the implementation of modern, active learning methods" with intention for systematic development people's entrepreneurial and consequently managerial characteristics. The results of empirical analyses which follows also confirms these hypotheses. 


\section{Implementing new, modern learning methods at the secondary school level (The Case of Slovenia)}

The highest percentage of Slovene entrepreneurs have high school education (Table 1), on the other hand, after finishing high school many youngsters opt for entrepreneurial career. It is therefore important to look at the implementation of active learning methods, especially in entrepreneurial education at the secondary school level, more closely.

With the intention to find out how modern learning methods are implemented and entrepreneurial characteristics developed at the secondary school level, we questioned 24 teachers and 174 pupils finishing secondary school about the progress made in replacing traditional teaching methods with active, student-oriented methods. The goal was also to discover the weaknesses and obstacles which affect the progress of educational modernization.

Students and teachers were offered a five-point scale including: 1 (for never), 2 (rarely), 3 (sometimes), 4 (usually) and 5 (always). The following conclusions can be drawn from empirical results based on response means:

- $\quad$ Students estimate the climate in classroom as positive; they are allowed to ask questions and express critical opinions (3.8), they get an extra explanation (4.2), discipline problems are rare (2.7), the working atmosphere is encouraging (3.5), students can express their feelings (3.2). Their teacher opinion was even better; the mean for similar questions ranked from 4.2 to 5.0.

- $\quad$ Student activity; Students find themselves active, solving mostly unstructured tasks and problems (3.8), they often work in pairs or groups (3.5). Teacher opinion ranked from 3.8 to 4.1 .

- Implementation of student-centered learning methods and development of entrepreneurial characteristics; student value was 3.3, whereas teachers were more optimistic at 4.1.

- $\quad$ Establishing the link between theory and real life; student value was 3.3, teacher opinion was higher, reaching 4.6.

- $\quad$ Student motivation; students find the subject of entrepreneurship interesting (2.8), teacher opinion (4.2)

- $\quad$ Knowledge; Evaluating is transparent, feedback is given for every mark, criteria are clear and discussed; student opinion (3.4); teacher opinion (4.4).

As part of the survey, students and teachers were asked about the structure of learning activities, used in teaching entrepreneurship. It is encouraging, that the greatest percent of responses was given to unstructured, student-centered activities (student opinion: 24\%; teacher opinion: 32\%), individual setting and solving authentic problems (student opinion: 23\%; teacher opinion: 29\%), unstructured cases and problems (student view: 18\%; teacher view: 17\%), structured problems and cases (student opinion: 18\%; teacher view: 14\%) and interpretation of definitions, formulas and data (student view: 17\%; teacher view: 8\%). Entrepreneurship lectures are mostly held in classroom, with students often working in pairs and teams.

Students came up with some problems and weaknesses of entrepreneurial education, including: (1) small size of classrooms, without access to computers and multimedia, (2) inflexible management and timetable which doesn't enable visiting entrepreneurs during school-time, (3) not enough time for current issue discussions, (4) lack of time for role playing and other activities etc.

In spite of some evident differences among student and teacher views on the problem, we can conclude that entrepreneurship is among the leading subjects in implementing modern learning methods in school system in Slovenia.

\section{Recommendations for Slovenia}

In spite of the fact that GEM experts (Glas, 2002) assessed entrepreneurial and especially managerial education in Slovenia quite highly, entrepreneurial culture in Slovenia still seems to be very low (Rihtarič, 1998). Considering the fact that most Slovenian entrepreneurs (47\%) and managers have finished secondary or vocational school (Vahčič, Glas, Petrin, 1998, p. 13) and taking into account the fact that Slovene entrepreneurs are very often 
forced to seek self-employment (necessity-based entrepreneurship activity - Figure 1 - is high) it is extremely important to encourage people to educate themselves more than they used to. Considering the findings of different analyses (Glas, 2002; Hisrich, 1995; Hynes, 2001; Hytti, 2002; Timmons, 1994; Vahčič et al, 1998 etc.) we can recommend the following:

(1) Entrepreneurial education should be involved at all levels of education, from the kindergarten up (Gibb, 1994, p. 32-36, Timmons, 1994, p. 18); Finland and Ireland for example, start with entrepreneurship programs at an early age (Table 2 ).

(2) Continuous education should be implemented through life-learning programs after finishing formal education (Hisrich, 1995, p. 183-186).

(3) Entrepreneurial education should be spread from business - oriented schools and faculties to all others; the system of entrepreneurial education has already been accepted in the USA, Great Britain, Australia, Finland, Sweden, Hungary and South Africa.

(4) An interdisciplinary-oriented entrepreneurial incubator acting as a model for real enterprises should be established.

(5) Entrepreneurial programs in Slovenia are separated and crumbled at different educational levels and not harmonized. They should be more extensive and spread through different educational levels ( Table 2).

(6) Entrepreneurial programs should be categorized under the following three headings: informative-oriented programs (learning to understand entrepreneurship and increasing the awareness of the entrepreneurship phenomenon), formative-oriented programs (learning to become an entrepreneur, developing entrepreneurial characteristics as well as increasing the entrepreneurial skills and knowledge) and finally a program which would support the implementation of entrepreneurial ideas in cooperation with the entrepreneurial incubator.

(7) Teachers should be more flexible, student-centered methods should be implemented at all school subject on a larger scale (teachers should be educated and trained, intending trainings in Slovenia, and international courses).

(8) The cooperation with educational institutions abroad should be strengthened, thus enabling internationalization of programs and continuous development of teachers, professors and other instructors of entrepreneurial education.

(9) The implementation of the stated suggestions should be empirically tested.

\section{Conclusion}

European countries, the USA and Australia have different entrepreneurial activities (entrepreneurial cultures) and the differences are reflected in the training programs, curricula structure, and the methods of training and evaluation adopted. In the USA, Australia, Finland and the UK, enterprise education means more than training for those who are interested in becoming self-employed, as enterprise education also encompasses training aimed at increasing the entrepreneurial behavior of students and employees. Finland and the UK, for example, widely implement active teaching methods in their curricula. In some countries, on the other hand, enterprise education exclusively refers to the training of those who are interested in becoming self-employed. Especially in Slovenia, traditional teaching methods should be replaced with active ones aimed at developing entrepreneurial characteristics and behavior of population in general. Therefore, it is important to establish a common frame of reference that would allow Europe-wide comparability in order to create new knowledge of enterprise education and facilitate transnational academic and pedagogic discussion and cooperation among theorists and practitioners in this field.

\section{References}

1. Badrljica Mihajlo: Spreminjanje strukture gospodarstva z razvojem malega gospodarstva. Ljubljana: Ekonomska fakulteta, diplomsko delo, 2002, 38 pgs. In Slovenian.

2. Begley Thomas M., Boyd David P.: Psychological Characteristics Associated with Performance in Entrepreneurial Firms and Smaller Businesses. V Livesay Harold C., ed.: Entrepreneurship and the Growth of Firms, Vol. I. Aldershot: Elgar, 1995. pp. 330-344. 
3. Birch D.: Dynamic Entrepreneurship and Job Creation: Lessons from the US Experience for Central and Eastern Europe. The Hague: V Abell D.F. Koellermeier T.: Dynamic Entrepreneurship in Central and Eastern Europe, 1993, pp. 13-23.

4. Bojović Vesna: Pomen podjetništva in inovativnosti pri prestrukturiranju gospodarstva: diplomsko delo. Ljubljana: Ekonomska fakulteta,1989. 50 pgs. In Slovenian.

5. Burton-Jones Alan: Knowledge capitalism. Oxford University Press Inc, New York, 1999, 237 pgs.

6. Chell Elizabeth, Haworth Jean, Brearley Sally: The Entrepreneurial Personality: Concepts, Cases and Categories. London: Routledge, 1991. 171 pgs.

7. Dragar Aleš: Predlog za razvoj celovitega sistema podjetniškega izobraževanja in usposabljanja v Sloveniji: magistrsko delo. Ljubljana: Ekonomska fakulteta, 1999. 119 p. In Slovenian.

8. Erikson Truls: Entrepreneurial Capital - The Emerging Venture`s Most Important Asset \& Competitive Advantage. V: Entrepreneurship research conference 2001. Babson: Babson College - Jonkoping International Business School, 2001.8 pgs.

9. European Commission: Green Paper, Entrepreneurship in Europe, Brussels, 2003, 25 pgs.

10. GEM, Slovenija 2002. Finance, ponedeljek, 18. november 2002, št. 220, pp. 17-20. In Slovenian.

11. Gibb Allan A.: The Enterprise Culture and Education. International Small Business Journal, 1994 , pp.11 - 33.

12. Fostering Entrepreneurship. Paris: OECD, 1998. 286 pgs.

13. Glas Miroslav, Drnovšek Mateja: Small Business in Slovenia: Expectations and Accomplishments, Paper presented at RENT XIII workshop, London. 1999. 22 pgs.

14. Glas Miroslav et al.: Podjetništvo - poskusni delovni zvezek. Ljubljana: Zavod Republike Slovenije za šolstvo, 2000. 74 pgs. In Slovenian.

15. Glas Miroslav, Drnovšek Mateja: Support for Graduate Students with Entrepreneurial Intentions: The case of Slovenia, Paper presented at ESBS 2001 - An Enterprise Odyssey, $31^{\text {st }}$ European Small Business Seminar, Dublin. 2001. 14 pgs.

16. Glas Miroslav: Ocena pogojev za podjetništvo v Sloveniji. Osnutek za raziskavo GEM, Slovenija 2002. 12/12-20026/1-2003. In Slovenian.

17. Hisrich Robert: Politika spodbujanja podjetništva v gospodarstvih v prehodu. Ljubljana: Slovenska ekonomska revija, letnik 46, 1995, št. 3, pp. 183-186. In Slovenian.

18. Hynes Briga: Encouraging Entrepreneurial Behavior in Non Business Students - The Issues in Programme Design. V: $31^{\text {st }}$ European Small Business Seminar. ESBS 2001- An Enterprise Odyssey: Dublin, Ireland, 12. - 14. September 2001. Dublin: Dublin Institute of Technology, 2001. Abstract, 1 p.

19. Hytti Ulla at al.: State-of-Art of Enterprise Education in Europe, Results from the Entredu project. Small Business Institute, Turku School of Economics and Business Administration, Finland. 2002. 60 pgs.

20. Marentič - Požarnik B.: Kako pomembna so pojmovanja znanja, učenja in poučevanja za uspeh kurikularne prenove. Ljubljana: Sodobna pedagogika 4. 1998. pp. 360-370.

21. Možina Stane et al.: Management. Radovljica: Didakta, 1994. 1072 pgs. In Slovenian.

22. Musek Janek: Psihološki portret Slovencev. Ljubljana: Znanstveno in publicistično središče, 1994 . 195 pgs. In Slovenian.

23. Reynolds Paul D., Camp S. Michael, Bygrave William D., Autio Erkko, Hay Michael: Global Entrepreneurship Monitor: 2001 Executive Report. London: Babson College, Kauffman Center for Entrepreneurial Leadership, London Business School, 2001. 57 pgs.

24. Rihtarič Mira: Education and Training Needs arising from Opening/Integration of Markets - A Case of Slovenia. University of Maribor, Paper prepared for the 8th global IntEnt Conference, 1998. 7pgs.

25. Setnikar-Cankar Stanka: Vloga in pomen podjetništva kot dejavnika gospodarskega razvoja: doktorska disertacija. Ljubljana: Ekonomska fakulteta, 1993. 207 pgs. In Slovenian.

26. Sisan Ana: Podjetniška kultura v Sloveniji: magistrsko delo. Ljubljana: Ekonomska fakulteta, 2000.80 p. In Slovenian.

27. Slovenija v številkah (Slovenia in figures) 2002. Ljubljana: Statistični urad RS, 2002. In Slovenian.

28. Smallbone David: Supporting SME Development in Economies in Transition: A View from the West. Paper presented at the conference: »Industrial Organisation and Entrepreneurship in Transition«, Varna, Bulgaria, June 1995, 10 pgs.

29. Statistični letopis Republike Slovenije 2001. Ljubljana: Statistični urad RS, 2001. (Statistical Yearbook of Slovenia, 2001). In Slovenian.

30. Timmons Jeffry A.: Podjetništvo kot obvezno znanje. Ljubljana: Podjetnik, 1994, št. 8, p. 18. In Slovenian.

31. Trstenjak Anton: Misli o slovenskem človeku. Ljubljana: Slovenska knjiga, 1991. 203 pgs. In Slovenian.

32. Vahčič Aleš., Glas Miroslav, Petrin Tea: Experiences with the Entrepreneurship Education in Slovenia. IntEnt98 International Conference on Entrepreneurship Education - European Business School, 1998. 16 pgs.

33. Vahčič Aleš: Stanje podjetništva v Sloveniji. Economic and business review, vol.2, posebna številka, »Slovensko podjetje v devetdesetih«, 2000. pp. 49-59. In Slovenian.

34. Vidovič-Tomanovič Maja: Pomen malih in srednjih podjetij v Sloveniji pri vključevanju v Evropsko unijo. Bilten MMP, Ekonomsko-Poslovna fakulteta Maribor, št. 1, letnik 4, 1999. In Slovenian. 